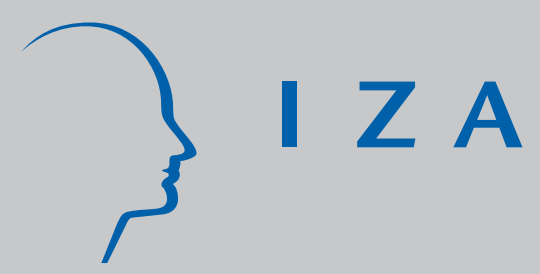

IZA DP No. 2623

Macroeconomic Impacts of Demographic Change in Scotland: A Computable General Equilibrium Analysis

Katya Lisenkova Karen Turner

Peter McGregor Robert E. Wright

Nikos Pappas

Kim Swales

February 2007 


\title{
Macroeconomic Impacts of Demographic Change in Scotland: A Computable General Equilibrium Analysis
}

Katya Lisenkova

University of Strathclyde

Peter McGregor

University of Strathclyde

Nikos Pappas

University of Strathclyde

Kim Swales

University of Strathclyde

Karen Turner

University of Strathclyde

Robert E. Wright

University of Strathclyde and IZA

Discussion Paper No. 2623

February 2007

IZA

\author{
P.O. Box 7240 \\ 53072 Bonn \\ Germany
}

Phone: +49-228-3894-0
Fax: +49-228-3894-180
E-mail: iza@iza.org

Any opinions expressed here are those of the author(s) and not those of the institute. Research disseminated by IZA may include views on policy, but the institute itself takes no institutional policy positions.

The Institute for the Study of Labor (IZA) in Bonn is a local and virtual international research center and a place of communication between science, politics and business. IZA is an independent nonprofit company supported by Deutsche Post World Net. The center is associated with the University of Bonn and offers a stimulating research environment through its research networks, research support, and visitors and doctoral programs. IZA engages in (i) original and internationally competitive research in all fields of labor economics, (ii) development of policy concepts, and (iii) dissemination of research results and concepts to the interested public.

IZA Discussion Papers often represent preliminary work and are circulated to encourage discussion. Citation of such a paper should account for its provisional character. A revised version may be available directly from the author. 


\section{ABSTRACT \\ Macroeconomic Impacts of Demographic Change in Scotland: A Computable General Equilibrium Analysis ${ }^{*}$}

This paper combines a multi-period economic Computable General Equilibrium (CGE) modelling framework with a demographic model to analyse the macroeconomic impact of the projected demographic trends in Scotland. Demographic trends are defined by the existing fertility-mortality rates and the level of annual net-migration. We employ a combination of a demographic and a CGE simulation to track the impact of changes in demographic structure upon macroeconomic variables under different scenarios for annual migration. We find that positive net migration can cancel the expected negative impact upon the labour market of other demographic changes. (Pressure on wages, falling employment). However, the required size of the annual net-migration is far higher than the current trends. The policy implication suggested by the results is that active policies are needed to attract migrants. We nevertheless report results when varying fertility and mortality assumptions. The impact of varying those assumptions is rather small.

JEL Classification: J11

Keywords: regional CGE modelling, ageing population, migration

Corresponding author:

Robert E. Wright

Department of Economics

University of Strathclyde

William Duncan Building

130 Rottenrow

Glasgow G4 0GE

Scotland

E-mail: r.e.wright@strath.ac.uk

\footnotetext{
* All authors are affiliated with the Fraser of Allander Institute, University of Strathclyde. McGregor, Swales, Turner and Wright are also affiliated with the Department of Economics, University of Strathclyde. McGregor and Swales are also affiliated with the Centre for Public Policy for Regions, Universities of Glasgow and Strathclyde.
} 


\section{Macroeconomic Impacts of Demographic Change in Scotland: A Computable General Equilibrium Analysis ${ }^{1}$}

\section{Introduction}

There is apprehension amongst policy makers about Scottish demographic trends. The principal UK Government Actuaries Department's (GAD) projections for the Scottish population to 2040 are shown in Figure 1.1. These projections indicate that under the principal assumptions concerning demographic parameters, by 2040 Scottish total and working age populations are $2.6 \%$ and $14.4 \%$ below the base year (2000) values respectively.

Demographic change has many economic implications. In the present paper we concentrate on the effect on the level of economic activity and we focus in particular on the labour market impacts. We use simulation techniques, combining a generic demographic model (POPGROUP) and a Computable General Equilibrium (CGE) model of Scotland (AMOS). We are particularly interested in the extent to which migration counteracts the negative effects of a declining and ageing population. This is of particular policy relevance as the Scottish Executive, through its Fresh Talent Initiative, is attempting to retain foreign students studying in Scottish higher education establishments, essentially attempting to increase immigration.

The paper is organised in the following way. Section 2 outlines the theoretical analysis of the economic effects of population change. Sections 3 and 4 detail the POPGROUP demographic model and the AMOS computable general equilibrium (CGE) economic model. Section 5 gives the economic impacts that would be associated with the principal UK Government Actuaries Department's (GAD) Scottish population projections. Section 6 identifies the extent to which net

\footnotetext{
${ }^{1}$ This research was funded under the ESRC/Scottish Executive's Scottish Demography Initiative; grant number Res-342-25-0002. We are grateful to Duncan McNiven of the General Register Office for Scotland, Kay Russell, Dermot Rhatigan and Jamie Carter from the Scottish Executive as well as Grant Allan from the Fraser of Allander Institute for their help and guidance through the course of this project.
} 
immigration to Scotland would reverse the changes associated with population ageing and decline. Section 7 is a short conclusion.

\section{Theoretical Analysis of the Impact of Population Change on the Aggregate Scottish Labour Market.}

In this section we provide the conceptual underpinning for the simulation results that are reported in Sections 5 and 6. We focus on the labour market, which is analysed using an aggregate labour supply and demand framework, an appropriate method given the economic issues raised by an ageing population. The analysis in this section is implicitly long run so that the identified equilibrium wage and employment levels are those towards which the economy is being attracted over time.

Figure 2.1 represents the interaction of the labour supply and general equilibrium labour demand curves in the unified Scottish labour market. We assume that there are no geographical or skill sub-markets within the Scottish economy and that labour can move freely between sectors. The analysis is comparative static in that it identifies the impact on the equilibrium real wage and employment of an exogenous demographic disturbance. $^{2}$ The upward sloping labour supply curve indicates that with a fixed working-age population, an increase in the real wage will increase the quantity of labour supplied. ${ }^{3}$ The labour demand curve represents the relationship between the quantity demanded of labour and the real wage in long-run equilibrium, with incomes and prices endogenous ${ }^{4}$. An important point is that this general equilibrium labour demand curve takes into account changes in regional competitiveness and household income as wages vary.

\footnotetext{
${ }^{2}$ An exogenous disturbance is a change in one of the parameters or variables within the model that is not determined by the model itself. In this case, for example, the working population is taken as determined elsewhere - and therefore exogenous - whilst the employment level is given by the model and is therefore endogenous.

${ }^{3}$ As explained in Section 4 we actually use a wage curve specification for the regional labour market. (Blanchflower and Oswald, 1994; Layard et a1. 1991). However, the wage curve approach gives results that are observationally equivalent to a labour supply curve although the interpretation is somewhat different.

${ }^{4}$ The general-equilibrium labour demand curve is drawn as downward sloping and this is the case in the model of the Scottish economy with default parameter values. However, for combinations of extreme product demand and factor substitution elasticities, the general equilibrium labour demand curve can be upward sloping (McGregor et al, 1995).
} 
Figure 2.1: The Labour Market in 2000 and in 2040

under the GAD population projections.

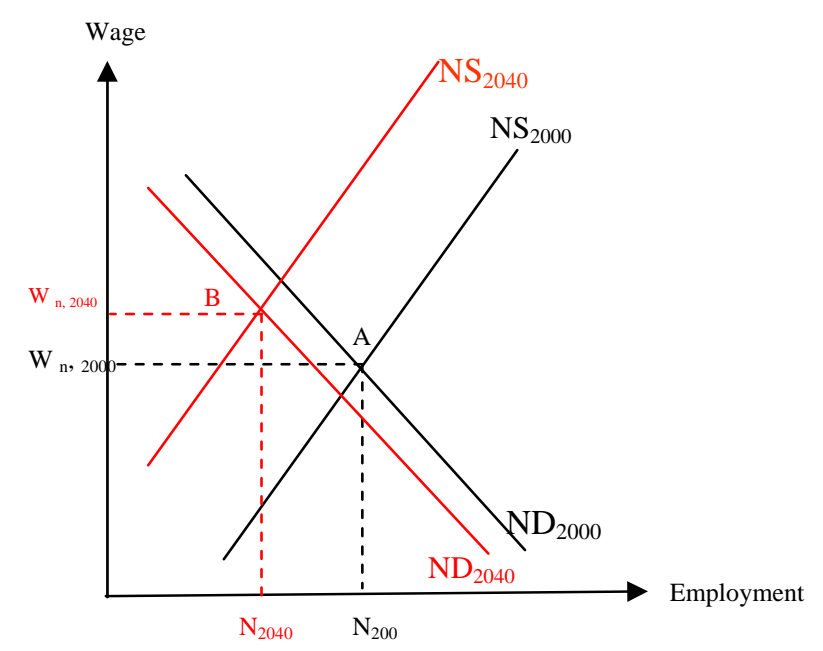

In Figure 2.1 we compare the long-run labour market equilibrium in 2040 with that in 2000, under the assumption that the Government Actuaries Department (GAD) population projections apply and that real per capita Scottish government expenditure remains constant (www.gad.gov.uk). The initial equilibrium is represented by point A, where the base-period (2000) labour demand and supply curves $\mathrm{ND}_{2000}$ and $\mathrm{NS}_{2000}$ intersect. This generates the initial equilibrium employment and real wage levels $\mathrm{W}_{\mathrm{n}, 2000}, \mathrm{~N}_{2000}$.

According to the GAD projection, over the period to 2040, the population in Scotland will decline and age. These exogenous changes in population size and age composition shift both the labour demand and supply schedules. First, the fall in the working age population reduces labour supply at each wage level generating an inward shift of the labour supply curve. This is illustrated in the Figure 2.1 by the new labour supply curve $\mathrm{NS}_{2040}$, which lies to the left of the original labour supply curve $\mathrm{NS}_{2000}$. However, the change in population also affects labour demand. Because total population has fallen, government expenditure is lower, so that labour demand also declines at each wage rate. This shifts the labour demand curve to the left, to $\mathrm{ND}_{2040}$. 
The new equilibrium is at point $B$, the intersection of the general equilibrium labour demand and supply curves $\mathrm{ND}_{2040}$ and $\mathrm{NS}_{2040}$. Both the labour demand and supply shifts lead to lower employment, whereas the impact on the wage depends on the relative size of the shifts. Our prior expectation is that the reduction in labour supply will be much greater than the reduction in labour demand. There are two reasons for this. First, the proportionate fall in the working age population is much greater than the fall in the population as a whole. Second, government expenditure is only one of the elements of final demand. Under these conditions, the larger proportionate reduction in labour supply will stimulate wage increases as the labour market tightens.

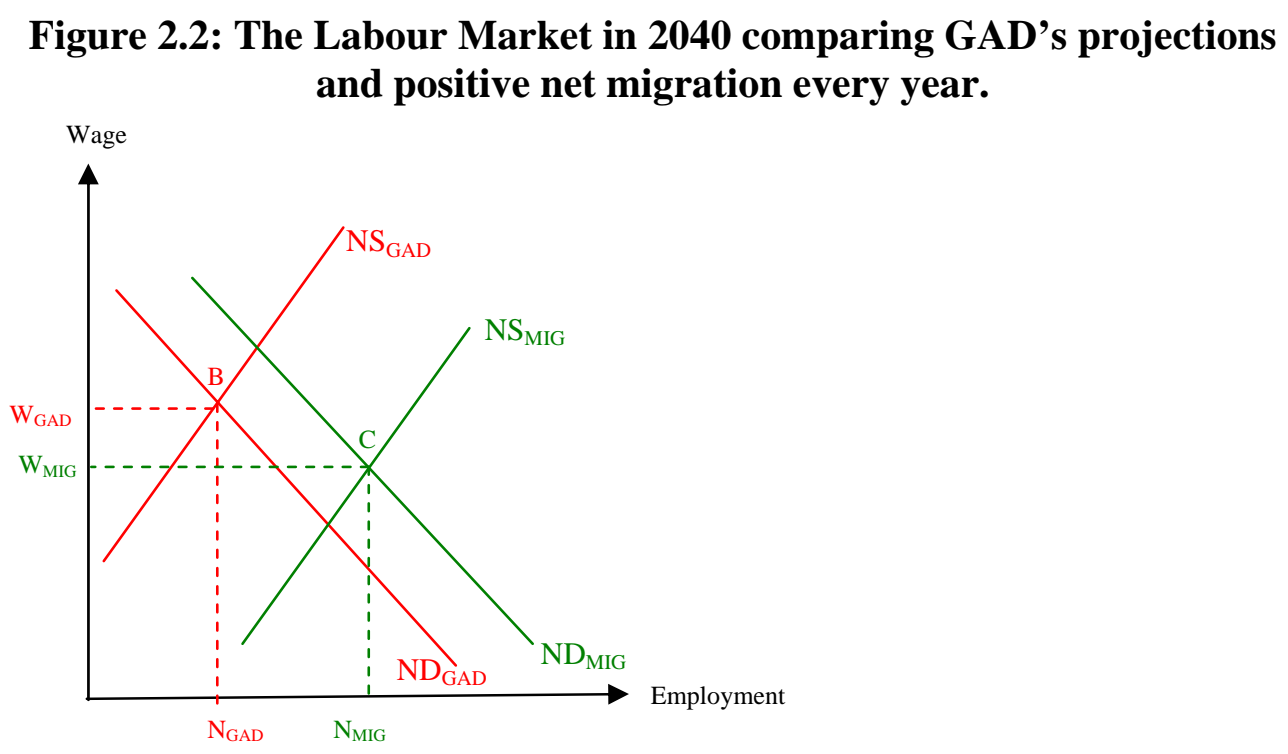

In Figure 2.2 we extend the analyses to show the impact on the labour market in 2040 of increased inward migration. Figure 2.2 compares the labour market in 2040 under two different scenarios. One simply takes the GAD population projections. The second represents a situation in which there is positive net in-migration, perhaps as a result of Scottish Executive policies, such as the Fresh Talent Initiative (www.scotlandistheplace.com).

The situation under the GAD projection is given by point $B$, which is the intersection of the labour demand and supply functions $\mathrm{NS}_{2040}, \mathrm{ND}_{2040}$. This was the 
final position illustrated in Figure 2.1. Now impose net in-migration at a rate higher than that assumed under GAD. The Scottish working age population, and therefore the Scottish labour force, is going to be higher than under the GAD prediction for 2040. This is illustrated in Figure 2.2 by an outward shift of the labour supply curve to $\mathrm{NS}_{\mathrm{MIG}}$. Labour demand will also shift outwards to $\mathrm{ND}_{\mathrm{MIG}}$ as a result of higher population-linked government expenditure. The new equilibrium is at point $C$, the intersection of the new labour supply and demand curves. In this case the shifts in labour demand and supply both work to increase equilibrium employment (compared to the equilibrium at B). Further, because we expect that the increase in labour supply will dominate the increase in labour demand, pressure in the labour market should ease and the wage fall.

Figures 2.1 and 2.2 show the qualitative impact of population ageing and inmigration on the labour market. These labour market changes will have major impacts on the economy overall. In particular, with an ageing population, we expect a negative effect upon competitiveness due to the increased wage, which is a key production cost. This reduced competitiveness has a negative impact on GDP. On the other hand, in-migration eases the labour market, improves competitiveness and increases GDP. However, the interactions within the economy are naturally more complex than this and are explored in the simulations reported in Sections 5 and 6. However, note that the figures reported these simulations are for time periods over which such long-run adjustment is not yet complete. Similarly, where we report period-by-period simulations, we are tracing out the adjustment path to the long-run equilibrium.

\section{POPGROUP: The Demographic Model.}

Demographic projections were produced using the POPGROUP software developed by the Cathie Marsh Centre for Census and Survey Research (CCSR) at the University of Manchester. POPGROUP uses the conventional cohort component method for the demographic projections. This method tracks each cohort and its mortality, fertility, and migration over time. Starting with a base population, year-byyear deaths are subtracted, and births and net immigration are added to the population. 
This program allows us to project future population by sex and age structure, based on the current age-sex structure and additional assumptions about the main demographic variables: mortality, fertility and migration.

A simple algebraic account of the model follows. The population of sex, $\mathrm{s}$, aged $\mathrm{x}$ +1 on his or her last birthday in year $t+1, P_{s}(x+1, t+1)$, is determined as the sum of two elements. The first is the population of sex s whose age at his or her last birthday in year $t$ was $x, P_{s}(x, t)$, who survive to the next year. The probability of survival is age, sex and time specific, and is given as $S_{s}(x+1, t+1)$. The second element is the level of net migration, which is again sex, age and time specific and given as $\mathrm{NM}_{\mathrm{s}}(\mathrm{x}+1, \mathrm{t}+1)$. Therefore:

$$
P_{s}(x+1, t+1)=P_{s}(x, t) S_{s}(x+1, t+1)+N M_{s}(x, t) \quad x \geq 0
$$

The population of sex s who are aged 0 in year $t+1$ is determined by the number of births in time $t, B_{s}(t)$, times the probability of surviving to period $t+1$ plus the number of migrants in this category, so that:

$$
P_{s}(0, t+1)=B_{s}(t) S_{s}(0, t+1)+N M_{s}(0, t)
$$

The birth rate is given by the population of females, $\mathrm{f}$, broken down by age, multiplied by the age specific fertility rates, ASFR :

$$
B(t)=\sum_{x} 0.5\left[P_{f}(x, t)+P_{f}(x, t+1)\right] \operatorname{ASFR}(x, t)
$$

with births divided between males and females according to the sex ratio of 106 males to 100 females. 
Adding up the components of change across ages and sexes, we obtain the total population in year $\mathrm{t}+1$ as:

$$
P(t+1)=P(t)+B(t)-D(t)+N M(t)
$$

where $\mathrm{D}(\mathrm{t})$ is the number of deaths and is given as:

$$
D(t)=\sum_{s} \sum_{x}\left\{P_{s}(x, t)\left[1-S_{s}(x+1, t+1)\right]\right\}+\sum_{s} B_{s}(t)\left[1-S_{s}(0, t+1)\right]
$$

In all the simulations the actual population structure estimated by the Government Actuaries Department (GAD) are used for the period from 2000 to 2004. The population projections therefore begin from 2004. Our projections are based on fertility and mortality assumptions employed by the GAD in their 2004-based principal Scottish population projection, which was published on October 20, $2005 .{ }^{5}$ Using this as a base we have produced several scenarios of population projections depending on the assumed level of migration. For the age distribution of migrants, we generally assume that $1 / 3$ are in the age group $0-19$ and $2 / 3$ in the age group $20-39$. Within these age groups, migrants are distributed equally by age and sex. This agesex structure can be summarized as "young couples with one child”.

\section{AMOS: The Economic Model.}

AMOS is an acronym for A Macro-Micro Model Of Scotland. It is best regarded as a Computable General Equilibrium modelling framework “... because it encompasses a range of behavioural assumptions, reflected in equations which can be activated and configured in many different ways” (Harrigan et al, 1991, p. 424). This allows the user to choose from a variety of model closures and key parameter values, as appropriate for particular applications. A good general description of CGE modelling is given in Greenaway et al (1992) and an extensive review of regional CGE models can be found in Partridge and Rickman (1998).

\footnotetext{
${ }^{5}$ Available from the GAD website $w w w . g a d . g o v . u k$, population projections section
} 
We have calibrated the AMOS modelling framework to data on the Scottish economy given in the form of a Social Accounting Matrix (SAM) for the year 2000. The model has 3 transactor groups - households, firms and government - and 2 exogenous external transactors - the rest of the UK (RUK) and the rest of the world (ROW). The model has 25 activities/commodities and these are listed in Table A1.1 in Appendix 1. A condensed account of the model structure is given in Table A2.1.

In the version of AMOS used here, production takes place in perfectly competitive industries using multi-level production functions. This means that in every time period all commodity markets are in equilibrium, with price equal to the marginal cost of production. Value-added is produced using capital and labour via standard production function formulations so that, in general, factor substitution occurs in response to relative factor-price changes. Typically, constant elasticity of substitution (CES) technology is adopted, which is the case in simulations reported here. ${ }^{6}$ In each industry intermediate purchases are modelled as the demand for a composite commodity with fixed (Leontief) coefficients. These are substitutable for imported commodities via an Armington link. The composite input then combines with valueadded (capital and labour) in the production of each sector's gross output. Cost minimisation drives the industry cost functions (equation 1 in Table A2.1) and the factor demand functions (equations 7 and 8 in Table A2.1).

Whilst the AMOS framework offers a wide choice of labour market closures, in the simulations reported here the labour market is characterised by a regional bargaining function (also expressed as a wage curve, represented as equation 5 in Table A2.1). This establishes a negative relationship between the real wage and the unemployment rate (Minford et al, 1994). Empirical support for this wage curve specification is now widespread, even in a regional context (Blanchflower and Oswald 1994). The bargaining function is parameterised using the regional econometric work reported in Layard et al. (1991):

$$
\ln r w_{n, t}=a-0.113 \ln u_{t}+0.40 \ln r w_{n, t-1}
$$

\footnotetext{
${ }^{6}$ Leontief and Cobb-Douglas options are available as special cases.
} 
where rw is the Scottish real wage, $\mathrm{u}$ is the Scottish unemployment rate, $t$ is the time subscript and a is a calibrated parameter. ${ }^{7}$ To transform the real wage to the nominal wage, we multiply by the consumer price index (equation 2 in Table A2.1).

Perfect labour mobility is assumed between sectors, generating a unified labour market. Therefore, although wage rates vary between sectors in the base-year data set, in the simulations wages in all sectors change by the same proportionate amount in response to exogenous shocks. The nominal wage in each time period is then derived through the interaction of the resulting wage curve and the general equilibrium labour demand curve (equation 9 in Table A2.1). In the derivation of the general equilibrium labour demand curve, it is important to note that all prices and incomes are taken to be endogenous.

The four main components of commodity final demand (represented by equation 12 in Table A2.1) are consumption, investment, government expenditure and exports. Household consumption is a linear homogenous function of real disposable income and relative prices (equations 2, 11 and 13 in Table A2.1). Real government expenditure per head is assumed to be constant (equation 17, Table A2.1) and in these simulations the population is typically determined exogenously using the demographic model. Exports are determined by exogenous external demand via an Armington link, making exports relative price sensitive (equation 18, Table A2.1).

The modelling of investment demand is a little more complex. In the multi-period variant of the model, capital stock adjustment at the sectoral level, which ultimately determines aggregate investment demand, is dealt with in the following way. Within each time period, both the total capital stock and its sectoral composition are fixed. The interaction between this fixed capital supply and capital demand at the sectoral level determines each sector's capital rental rate (equation 10, Table A2.1). The capital stock in each sector is then updated between periods via a simple capital stock adjustment procedure, according to which investment equals depreciation plus some fraction of the gap between the desired and actual level of the capital stock (equations

\footnotetext{
${ }^{7}$ The calibration is made so that the model, together with the set of exogenous variables, will recreate the base year data set. This calibrated parameter does not influence simulation outputs, but the assumption of initial equilibrium is, of course, important.
} 
6, 14 and 15 in Table A2.1). ${ }^{8}$ Desired capital stocks are determined on costminimisation criteria, using the user cost of capital as the relevant price of capital (equations 3 and 4 in Table A2.1). In the base period the economy is assumed to be in long-run equilibrium, where desired and actual capital stocks are equal, with investment simply equal to depreciation. Investment as a source of product demand is then determined by running the demand for increased capital stock by sector through the capital matrix (equation 16, Table A2.1).

In the model, we do not impose macro-economic constraints, such as balance of payments or budget deficit limits or targets. There is no reason for these to bind at the regional level. However, we do track these surpluses. We also interpret the conceptual time periods of the model as years: annual data are used for the calibration and, where applicable, the estimation of parameter values.

As stated earlier in this section, the structural characteristics of the AMOS model are parameterised on a Social Accounting Matrix (SAM) for Scotland for 2000. In all sectors, the elasticity of substitution between capital and labour in the production of value added is 0.3. However, we adopt fixed coefficients in the generation of the intermediate composite. This is required because of the large number of zero entries. The Armington trade elasticities for imports and exports are 2.0. The speed of adjustment parameter for the adjustment of actual to desired capital stock is 0.5 .

Before discussing the simulation results it is important to clarify a key characteristic of the AMOS model. AMOS is not a forecasting model. When it is parameterised on the base year data set, it is assumed that the economy is in long-run equilibrium. If there are no changes to the exogenous variables and the model is run in period-by-period mode, then the model will simply report an unchanging economy. In the simulation results that we report in sections 5 and 6 , the only exogenous changes that are introduced into the model are the direct government demand and labour force changes associated with the population projections. Therefore the results should be interpreted as deviations from what would have occurred with a population that is constant both in size and age composition.

\footnotetext{
${ }^{8}$ This process of capital accumulation is compatible with a simple theory of optimal firm behaviour given the assumption of quadratic adjustment costs. The whole process is analogous to Tobin's q.
} 


\section{The Consequences for the Scottish Economy of the Government Actuaries Department (GAD) Population Projections.}

The assumptions underlying the principal GAD projection for Scotland are a fertility rate of 1.6, life expectancies of 79.2 years for men and 83.7 for women and net immigration at a constant level of 4000 per annum. In Figure 1.1 we tracked the percentage changes from the base year in total population and total working-age population generated by these assumptions. According to this scenario, the working age population is expected to fall below its base year (2000) value in 2012 and decline by $19.08 \%$ by 2040 . Total population falls below the base-year value in 2032 and is $2.62 \%$ below it by 2040 .

The demographic data represented in Figure 1.1 are used to generate exogenous disturbances in the AMOS model as discussed in Section 4. This gives the simulation results summarised in Table 5.1.

\section{Table 5.1 here}

As we explain in Section 2, the population change produces two simultaneous exogenous impacts. One operates on the demand side and the other on the supply side. Changes in total population affect the demand side, generating changes in government demand as we hold real per capita government expenditure constant. Changes in working age population are modelled as supply-side changes, operating through adjustments in the labour force, which affect the tightness of the labour market.

One important technical point needs to be made here. We can enter the period-byperiod government demand changes so that they precisely match the period-by-period changes in population. However, as the model is presently configured, we can only impose changes in the labour force by means of a linear trend. Therefore, for example, with the GAD projection shown in Figure 5.1 above, the $14 \%$ fall in the working age population over the 40 years between 2000 and 2040 is modelled as a linear reduction in the labour force equal to an annual rate of $0.5 \%$ of the original 2000 value. This means that whilst the end-point simulation results are correct, there is some loss of accuracy in the adjustment path. ${ }^{9}$

\footnotetext{
${ }^{9}$ In fact, the imposed adjustment path will affect the endpoint results, but this should be small.
} 
In interpreting the results in Table 5.1, it is important to remember that these should be interpreted as variations away from what would have occurred with population held constant in both size and age composition. Begin by looking at the Scottish employment and GDP figures. As we expect from the theoretical discussion in Section 2, employment falls, in this case by $9.0 \%$ in 2040 , with a corresponding decline in GDP of a little less at $8.2 \%$. Note that because of the linearisation of the change in the working age population in the model, the results shown in Figure 5.2 will overestimate the reduction in the initial years, where an increase in output and employment is expected, but underestimate the rate (but not the level) of decline in the latter period of the simulation where working age population is falling.

Table 5.1 reveals two important points. The first is that the fall in employment is much lower than the fall in working age population. Working age population falls by $14.4 \% \%$ whilst employment only declines by $9.0 \%$, implying an increase in the participation rate and a fall in the unemployment rate to partially offset the negative supply side impacts. This tightening of the Scottish labour market is apparent in the real wage results where the real Scottish take-home wage of increases by $7.7 \%$ by the year $2040 .^{10}$.

The second key point is that the fall in GDP closely follows the decline in employment. In considering the fall in GDP, there are both demand and supply side effects to consider. From the demand side, the fall is primarily driven by a reduction in Scottish exports generated by the decline in Scottish competitiveness that accompanies the tighter labour market. Table 5.1 shows the Scottish consumer and export price indices. Note that consumer price index increase by $2.6 \%$ to 2040, but the increase in export price index is even higher, at 3.4\%. ${ }^{11}$ As a consequence, the demand for exported goods falls by 6.4\%. From the supply side, the capital stock will adjust to changes in output demand but more slowly than the changes in employment in particular sectors so that the change in GDP will slightly lag the changes in employment. There will also be a tendency for production to become more capital

\footnotetext{
${ }^{10}$ There is not full pass through of the increased wages to prices, that is prices increase by less than wages, primarily because of the presence of imports from outwith Scotland as elements of the consumption basket and as intermediate inputs in production.

${ }^{11}$ We measure the price of the exported good as the weighted average of export prices using base year weights.
} 
intensive as the nominal wage increases, so that there is some substitution of capital for labour.

\section{Figure 5.1 here}

Figure 5.1 shows the expected changes by 2040 in sectoral output and employment generated by the GAD demographic projections for Scotland. Note first that these simulations do not take into account any variation in the composition of government and household consumption demand that will be driven by population ageing. For example, there is much discussion of the implications for health care and education provision resulting from longer life expectancy (Economic Policy Committee and European Commission, 2006). Such compositional demand changes are not considered here. These disaggregated results therefore primarily reflect more general demand-side factors. These are the extent to which the sector supplies export, investment, household consumption or government demand.

Figure 5.1 indicates that by 2040 all sectors will be affected negatively. However, there is a wide variation in the impacts, ranging from an output reduction of 2.8\% for Public Administration to $11.8 \%$ for Construction. In general those sectors selling most of their output to government demand (Public Administration, Social Work, Health, Education) are affected least because government expenditure, which in these simulations is linked to total population, remains relatively constant over the whole simulation period, falling by only $2.6 \%$ by 2040 . In addition these sectors are sheltered in the sense that they are not subject to international competition.

The extent of the negative effect upon other sectors (which are mostly hit much harder) is determined by two factors. First, labour intensive sectors are worst affected because of the increased cost of labour. Second, the sectors that are more exposed to international trade feel the negative competitiveness effect more strongly. For example, sectors such as Agriculture clearly suffer these negative competitiveness effects. However, Other Manufacturing, which is the most export intensive sector, is not so severely hit because it is not labour intensive. In all sectors, employment falls by more than output because, as the price of labour rises, firms substitute labour for capital. Also, it takes more time to optimally adjust the capital stock. 


\section{A Wider Range of Migration Scenarios.}

We have tested how sensitive these economic results are to changes in the demographic parameters. These parameters are the birth rate, the male and female life expectancy, and the migration rate. The demographic variable with the biggest economic impact is the rate of in-migration, and it is this variable that has attracted the most policy interest. Figure 6.1 shows the GDP changes over time under the high, principal and low values for Scottish net in-migration given by GAD. In the principal GAD Scottish projections, the net in-migration is set at 4,000 per annum. GAD suggests 12,000 in-migrants and 4,500 out-migrants as appropriate high and low annual values for migration.

\section{Figure 6.1 here}

We here extend this analysis of the impact of migration by performing a range of simulations where we vary the migration rate, whilst holding the other demographic parameters constant at their GAD principal values. Specifically we report simulations where the annual rate of in-migration is: $-10,000$, zero, 4,000 (the current GAD principal projection), 5,000, 10,000, 20,000, 30,000, 40,000, 50,000, and 60,000. Summaries for all these simulations are given in Table 8.1. For the simulations with migration rates that differ from those for which we have GAD projections, we undertake the demographic simulations using the POPGROUP model. The subsequent time sequences for total and working age population are then used as exogenous shocks in the AMOS model.

\section{Table 6.1 here}

We focus attention here on a subset of five indicative migration scenarios, together with the GAD principal projection. These are for Scottish in-migration of 10,000 , zero, $10,000,20,000$ and 40,000 per annum. The first key point is that for the only with an immigration of above 10,000 per annum is total population projected to be greater than the base year (2000) value in 2040, and only with an immigration of above 20,000 per annum is working age population higher. 
In Figures, 6.2, 6.3, 6.4, and 6.5 we present the changes in GDP, employment, real wage, and the price of exported goods for the whole range of migration scenarios. The economic results are consistent with the analysis in Section 2 and the demographic information given in Table 6.1. We begin with Figure 6.2 and 6.3, which give the percentage changes in GDP and employment. Note that only for net migration rate of 20,000 per annum and over do GDP and employment levels rise as a result of population change. With in-migration values below this, both GDP and employment fall.

\section{Figure 6.2 here}

Figure 6.3 here

Figure 6.4 here

Figure 6.5 here

The mechanisms driving these results stem primarily from the labour market and the subsequent impact on competitiveness. Figure 6.4 shows the real wage change associated with the different migration scenarios. In this case, the 20,000 in-migration case generates a small increase in the real wage. We know that in this simulation, the working age population is rising, but more slowly than the total population. In terms of the analysis in Section 2, the outward shift of the labour demand curve, as government expenditure rises in line with total population, is greater than the outward shift in the labour supply curve as the working age population increases. There is therefore an increase in employment but also a small increase in the wage. However, for the examples where in-migration is less than 20,000, the wage increase is much greater and is not accompanied by any expansion in government expenditure. The tightening of the labour market is reflected in reduced competitiveness, with the price of exported goods falling only for those simulations where in-migration is greater than 20,000 per annum.

These results suggest that immigration has a positive impact on economic activity but that immigration of around 20,000 per annum is required in order to fully offset the negative effects of a "naturally" declining and ageing population. This level of in-migration will prevent working age population from shrinking up to 2040. 


\section{Conclusions}

In this paper we explore the macroeconomic consequences of the principal GAD projected declining and ageing population in Scotland using methods which combine both the POPGROUP demographic model and the AMOS economic model for Scotland. Our main conclusion is that the resulting tightening of the labour market will have adverse consequences for the Scottish employment level, growth and competitiveness. For the principal GAD demographic projections by 2040 Scottish total and working age populations are $2.6 \%$ and $14.4 \%$ below the base year (2000) values. This generates a fall in Scottish employment and GDP of 9.0\% and 8.2\% respectively below the levels that would have occurred had the population size and composition remain constant.

The impact that demographic change might have on economic activity has been a concern for Scottish policy makers. The demographic variable with the biggest economic impact is the rate of in-migration, and it is this variable that has attracted the most policy interest. The advantage of increased net in-migration is that immigrants are mainly of working age and are accompanied by children. However, if current demographic trends continue, policy initiatives, such as the Scottish Executive's Fresh Talent Initiative need to produce a positive annual net in-migration of 20,000 in order to prevent the labour force shrinking by 2040 .

There are, of course, issues that merit further investigation and may play a crucial role in forming future macroeconomic trends in the light of changing demographics. Two seem particularly significant. First there will be effects upon the composition of both private and public sector consumption demand associated with population ageing. This concerns not only the differences in the tastes and needs as an individual ages but also issues such as the political power of older voters. Secondly, if young and old workers are qualitatively different, with different skills and other work characteristics, the ageing of the workforce will generate qualitative labour market effects not captured in the AMOS model at present. This will affect not only the overall productivity of the workforce but also potentially the distribution of wage income between young and old workers. 
Figure 1.1- Percentage changes in working age and total population according to the principal GAD projection.

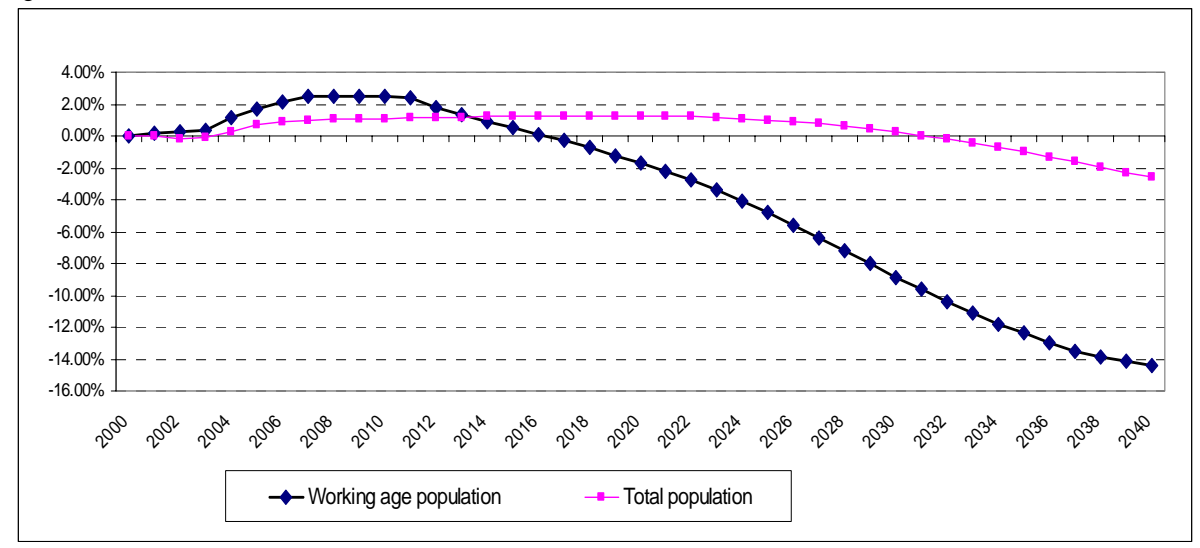

Table 5.1- Percentage change of aggregate economic and demographic variables under the principal GAD projection

\begin{tabular}{|l|r|r|r|r|r|r|}
\hline \multicolumn{1}{|c|}{ GAD } & $\mathbf{2 0 0 0}$ & $\mathbf{2 0 0 5}$ & $\mathbf{2 0 1 0}$ & $\mathbf{2 0 2 0}$ & $\mathbf{2 0 3 0}$ & $\mathbf{2 0 4 0}$ \\
\hline GDP & $0.00 \%$ & $-0.42 \%$ & $-1.12 \%$ & $-3.03 \%$ & $-5.41 \%$ & $-8.15 \%$ \\
\hline Real wage & $0.00 \%$ & $1.12 \%$ & $2.15 \%$ & $4.12 \%$ & $5.98 \%$ & $7.65 \%$ \\
\hline Working Age Population & $0.00 \%$ & $1.71 \%$ & $2.50 \%$ & $-1.69 \%$ & $-8.87 \%$ & $-14.37 \%$ \\
\hline Total Population & $0.00 \%$ & $0.67 \%$ & $1.09 \%$ & $1.28 \%$ & $0.25 \%$ & $-2.62 \%$ \\
\hline Total employment & $0.00 \%$ & $-0.60 \%$ & $-1.43 \%$ & $-3.54 \%$ & $-6.07 \%$ & $-8.97 \%$ \\
\hline Competitiveness index & $0.00 \%$ & $0.26 \%$ & $0.62 \%$ & $1.51 \%$ & $2.48 \%$ & $3.39 \%$ \\
\hline CPI & $0.00 \%$ & $0.20 \%$ & $0.46 \%$ & $1.14 \%$ & $1.88 \%$ & $2.55 \%$ \\
\hline
\end{tabular}

Figure 5.1- Impact on sectoral output and employment. (Percentage changes by the year 2040.

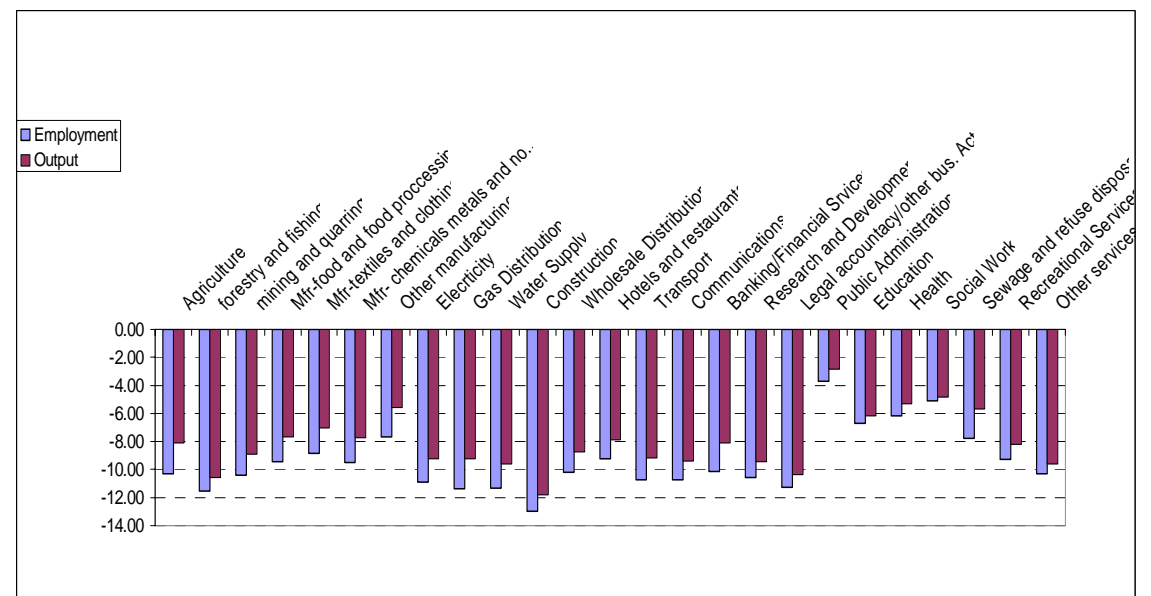


Figure 6. 1 Trends of GDP for alternative migration assumptions

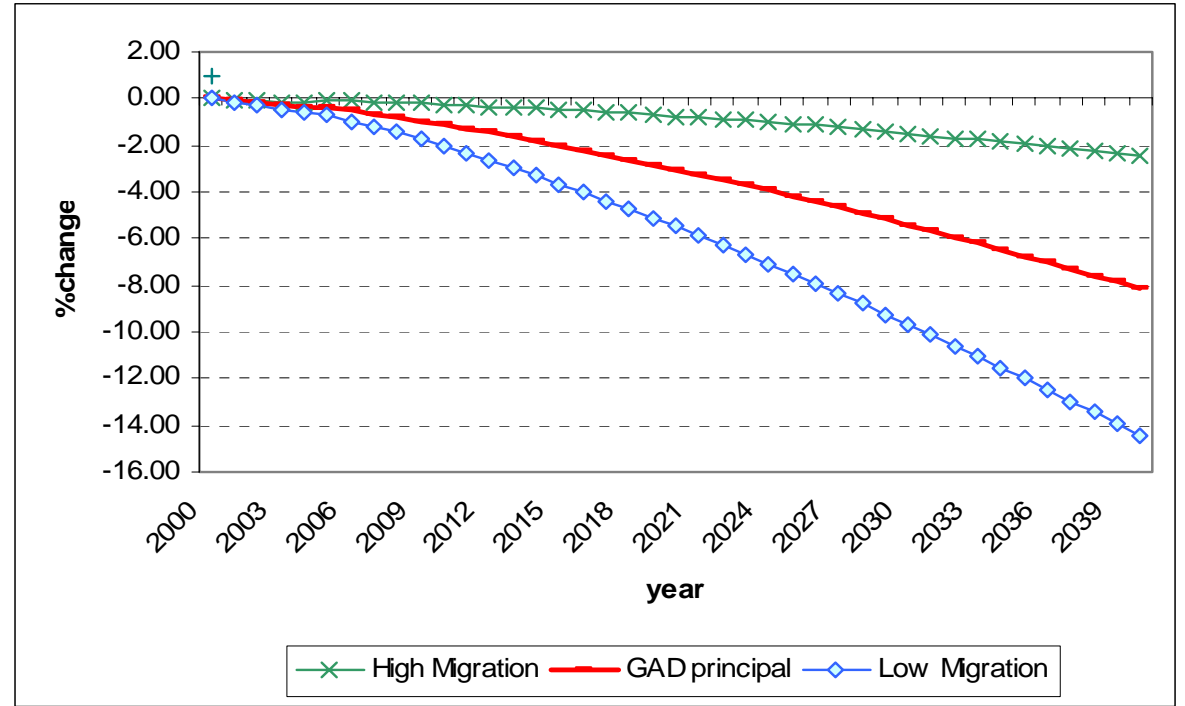


Table 6. 1 Main aggregate economic indicators for different net migration scenarios

\begin{tabular}{|c|c|c|c|c|c|c|}
\hline neg10000 & 2000 & 2005 & 2010 & 2020 & 2030 & 2040 \\
\hline GDP & 0.00 & -1.08 & -2.92 & -7.77 & -13.69 & -20.37 \\
\hline Real wage & 0.00 & 2.23 & 4.28 & 8.67 & 13.58 & 19.09 \\
\hline Working Age Population & 0.00 & 0.95 & -0.30 & -8.07 & -19.63 & -29.73 \\
\hline Total Population & 0.00 & 0.06 & -1.32 & -4.64 & -9.60 & -16.69 \\
\hline Total Employment & 0.00 & -1.49 & -3.68 & -9.03 & -15.35 & -22.39 \\
\hline Competitiveness index & 0.00 & 0.46 & 1.10 & 2.93 & 5.25 & 7.94 \\
\hline $\mathrm{CPI}$ & 0.00 & 0.31 & 0.74 & 2.09 & 3.79 & 5.66 \\
\hline Zero & 2000 & 2005 & 2010 & 2020 & 2030 & 2040 \\
\hline GDP & 0.00 & -0.72 & -1.91 & -5.03 & -8.85 & -13.19 \\
\hline Real wage & 0.00 & 1.58 & 3.04 & 6.04 & 9.15 & 12.29 \\
\hline Working Age Population & 0.00 & 1.17 & 1.17 & -3.86 & -12.16 & -19.08 \\
\hline Total Population & 0.00 & 0.26 & -0.08 & -1.01 & -3.28 & -7.53 \\
\hline Total Employment & 0.00 & -1.01 & -2.42 & -5.85 & -9.93 & -14.53 \\
\hline Competitiveness index & 0.00 & 0.34 & 0.81 & 2.12 & 3.66 & 5.29 \\
\hline $\mathrm{CPI}$ & 0.00 & 0.23 & 0.57 & 1.56 & 2.71 & 3.90 \\
\hline GAD & 2000 & 2005 & 2010 & 2020 & 2030 & 2040 \\
\hline GDP & 0.00 & -0.42 & -1.12 & -3.03 & -5.41 & -8.15 \\
\hline Real wage & 0.00 & 1.12 & 2.15 & 4.12 & 5.98 & 7.65 \\
\hline Working Age Population & 0.00 & 1.71 & 2.50 & -1.69 & -8.87 & -14.37 \\
\hline Total Population & 0.00 & 0.67 & 1.09 & 1.28 & 0.25 & -2.62 \\
\hline Total Employment & 0.00 & -0.60 & -1.43 & -3.54 & -6.07 & -8.97 \\
\hline Competitiveness index & 0.00 & 0.26 & 0.62 & 1.51 & 2.48 & 3.39 \\
\hline $\mathrm{CPI}$ & 0.00 & 0.20 & 0.46 & 1.14 & 1.88 & 2.55 \\
\hline 5000 & 2000 & 2005 & 2010 & 2020 & 2030 & 2040 \\
\hline GDP & 0.00 & -0.44 & -1.13 & -2.93 & -5.18 & -7.78 \\
\hline Real wage & 0.00 & 1.03 & 1.98 & 3.84 & 5.60 & 7.13 \\
\hline Working Age Population & 0.00 & 1.29 & 1.90 & -1.76 & -8.41 & -13.75 \\
\hline Total Population & 0.00 & 0.36 & 0.55 & 0.83 & -0.12 & -2.92 \\
\hline Total Employment & 0.00 & -0.62 & -1.44 & -3.42 & -5.81 & -8.57 \\
\hline Competitiveness index & 0.00 & 0.23 & 0.55 & 1.40 & 2.31 & 3.16 \\
\hline $\mathrm{CPI}$ & 0.00 & 0.17 & 0.40 & 1.05 & 1.75 & 2.38 \\
\hline 10000 & 2000 & 2005 & 2010 & 2020 & 2030 & 2040 \\
\hline GDP & 0.00 & -0.24 & -0.57 & -1.47 & -2.66 & -4.14 \\
\hline Real wage & 0.00 & 0.65 & 1.29 & 2.55 & 3.65 & 4.50 \\
\hline Working Age Population & 0.00 & 1.41 & 2.60 & 0.34 & -4.69 & -8.41 \\
\hline Total Population & 0.00 & 0.45 & 1.17 & 2.65 & 3.04 & 1.66 \\
\hline Total Employment & 0.00 & -0.34 & -0.74 & -1.71 & -2.98 & -4.54 \\
\hline Competitiveness index & 0.00 & 0.15 & 0.39 & 0.99 & 1.59 & 2.08 \\
\hline $\mathrm{CPI}$ & 0.00 & 0.12 & 0.31 & 0.78 & 1.24 & 1.60 \\
\hline
\end{tabular}


Table 6.1 (Continued)

\begin{tabular}{|c|c|c|c|c|c|c|}
\hline 20000 & 2000 & 2005 & 2010 & 2020 & 2030 & 2040 \\
\hline GDP & 0.00 & 0.16 & 0.50 & 1.28 & 1.98 & 2.48 \\
\hline Real wage & 0.00 & -0.06 & 0.04 & 0.32 & 0.51 & 0.49 \\
\hline Working Age Population & 0.00 & 1.66 & 4.04 & 4.58 & 2.78 & 2.24 \\
\hline Total Population & 0.00 & 0.65 & 2.43 & 6.30 & 9.34 & 10.84 \\
\hline Total Employment & 0.00 & 0.21 & 0.61 & 1.49 & 2.26 & 2.80 \\
\hline Competitiveness index & 0.00 & 0.01 & 0.10 & 0.29 & 0.42 & 0.43 \\
\hline $\mathrm{CPI}$ & 0.00 & 0.04 & 0.14 & 0.32 & 0.41 & 0.39 \\
\hline 30000 & 2000 & 2005 & 2010 & 2020 & 2030 & 2040 \\
\hline GDP & 0.00 & 0.53 & 1.51 & 3.82 & 6.19 & 8.41 \\
\hline Real wage & 0.00 & -0.73 & -1.08 & -1.52 & -1.91 & -2.40 \\
\hline Working Age Population & 0.00 & 1.84 & 5.50 & 8.79 & 10.29 & 12.88 \\
\hline Total Population & 0.00 & 0.85 & 3.67 & 9.95 & 15.66 & 20.01 \\
\hline Total Employment & 0.00 & 0.72 & 1.87 & 4.45 & 7.03 & 9.40 \\
\hline Competitiveness index & 0.00 & -0.12 & -0.15 & -0.27 & -0.47 & -0.77 \\
\hline $\mathrm{CPI}$ & 0.00 & -0.03 & 0.00 & -0.05 & -0.22 & -0.49 \\
\hline 40000 & 2000 & 2005 & 2010 & 2020 & 2030 & 2040 \\
\hline GDP & 0.00 & 0.89 & 2.47 & 6.19 & 10.09 & 13.84 \\
\hline Real wage & 0.00 & -1.37 & -2.09 & -3.07 & -3.83 & -4.57 \\
\hline Working Age Population & 0.00 & 2.08 & 6.96 & 13.03 & 17.76 & 23.56 \\
\hline Total Population & 0.00 & 1.05 & 4.94 & 13.61 & 21.98 & 29.19 \\
\hline Total Employment & 0.00 & 1.22 & 3.08 & 7.22 & 11.45 & 15.47 \\
\hline Competitiveness index & 0.00 & -0.23 & -0.38 & -0.74 & -1.17 & -1.66 \\
\hline $\mathrm{CPI}$ & 0.00 & -0.10 & -0.12 & -0.35 & -0.71 & -1.15 \\
\hline 50000 & 2000 & 2005 & 2010 & 2020 & 2030 & 2040 \\
\hline GDP & 0.00 & 1.24 & 3.37 & 8.41 & 13.71 & 18.87 \\
\hline Real wage & 0.00 & -1.96 & -3.01 & -4.38 & -5.38 & -6.25 \\
\hline Working Age Population & 0.00 & 2.33 & 8.40 & 17.24 & 25.23 & 34.20 \\
\hline Total Population & 0.00 & 1.24 & 6.18 & 17.26 & 28.30 & 38.36 \\
\hline Total Employment & 0.00 & 1.70 & 4.22 & 9.82 & 15.57 & 21.11 \\
\hline Competitiveness index & 0.00 & -0.35 & -0.58 & -1.12 & -1.72 & -2.34 \\
\hline $\mathrm{CPI}$ & 0.00 & -0.16 & -0.22 & -0.58 & -1.08 & -1.64 \\
\hline 60000 & 2000 & 2005 & 2010 & 2020 & 2030 & 2040 \\
\hline GDP & 0.00 & 1.57 & 4.23 & 10.51 & 17.13 & 23.62 \\
\hline Real wage & 0.00 & -2.52 & -3.84 & -5.51 & -6.65 & -7.59 \\
\hline Working Age Population & 0.00 & 2.57 & 9.83 & 21.45 & 32.71 & 44.84 \\
\hline Total Population & 0.00 & 1.44 & 7.43 & 20.92 & 34.62 & 47.54 \\
\hline Total Employment & 0.00 & 2.16 & 5.31 & 12.28 & 19.45 & 26.43 \\
\hline Competitiveness index & 0.00 & -0.45 & -0.75 & -1.44 & -2.16 & -2.86 \\
\hline $\mathrm{CPI}$ & 0.00 & -0.21 & -0.30 & -0.76 & -1.37 & -2.01 \\
\hline
\end{tabular}


Figure 6. 2 - Trends of GDP for alternative migration scenarios

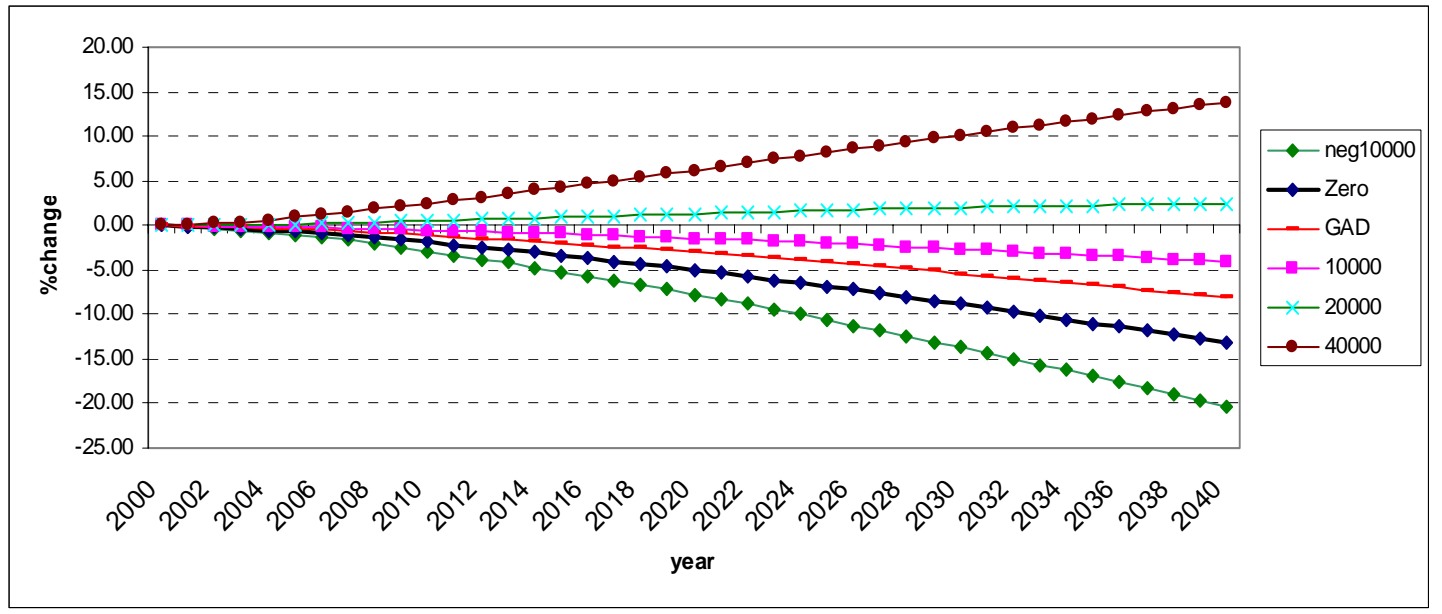

Figure 6.3- Trends of employment for alternative migration scenarios

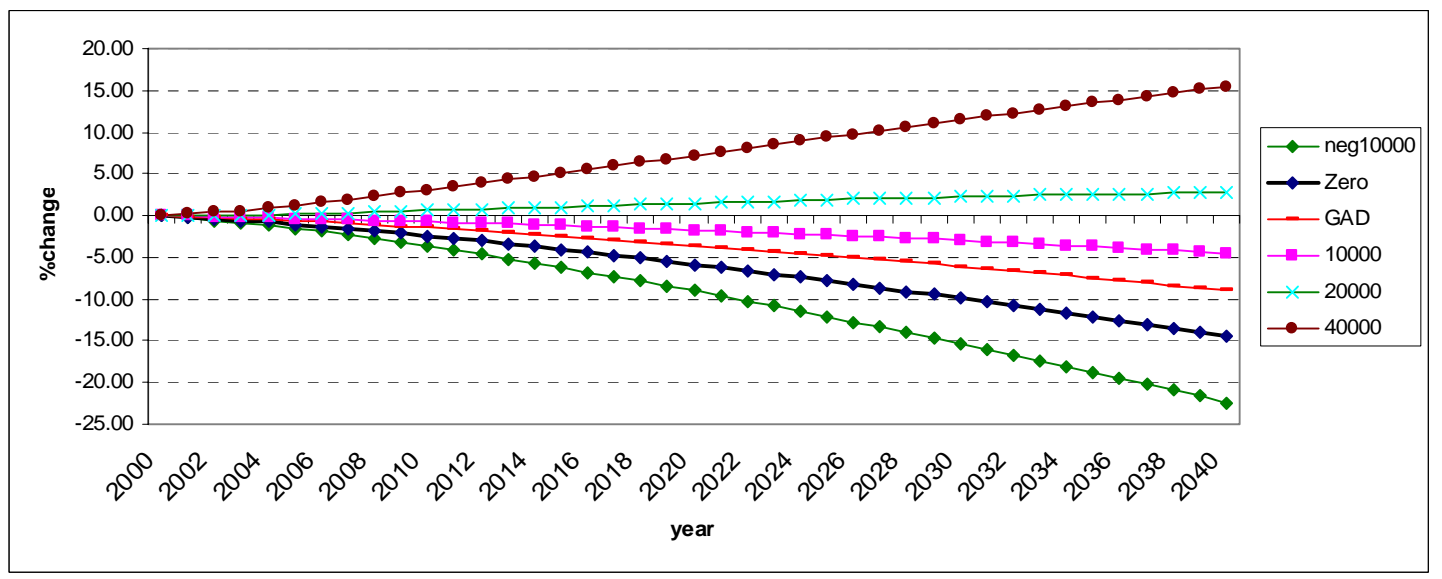

Figure 6. 4 Trends of real wage for alternative migration scenarios

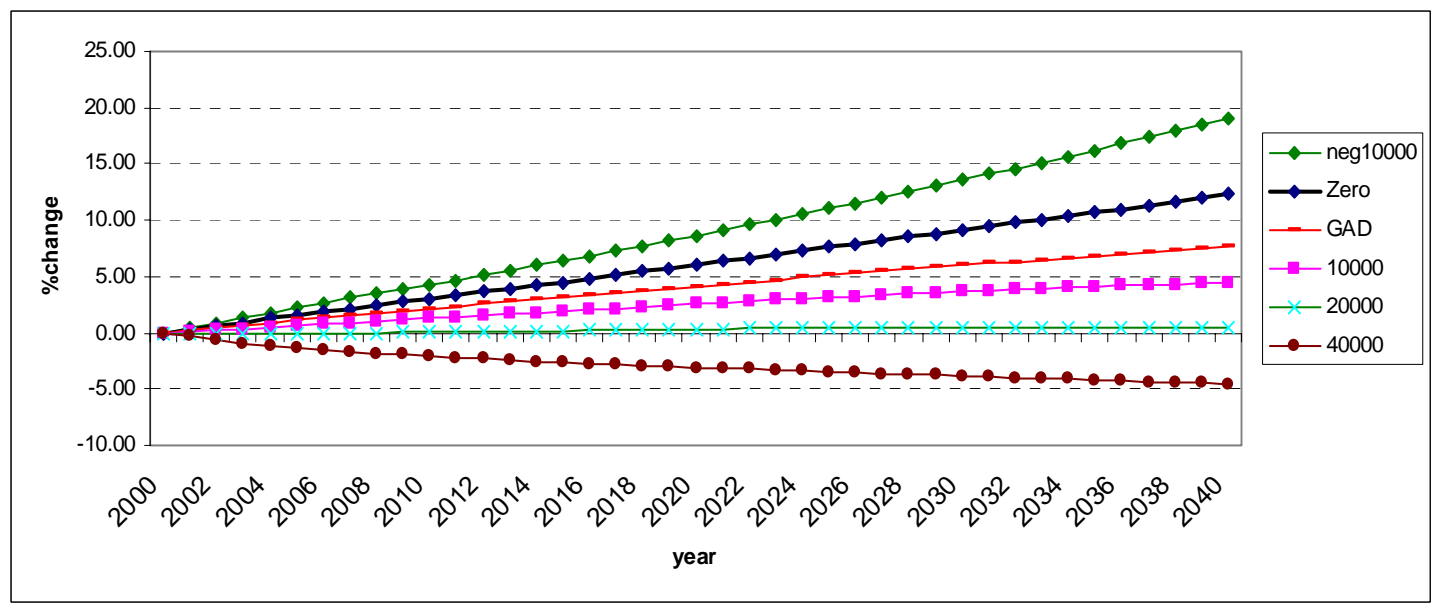


Figure 6. Trends of price of exported goods for alternative migration scenarios

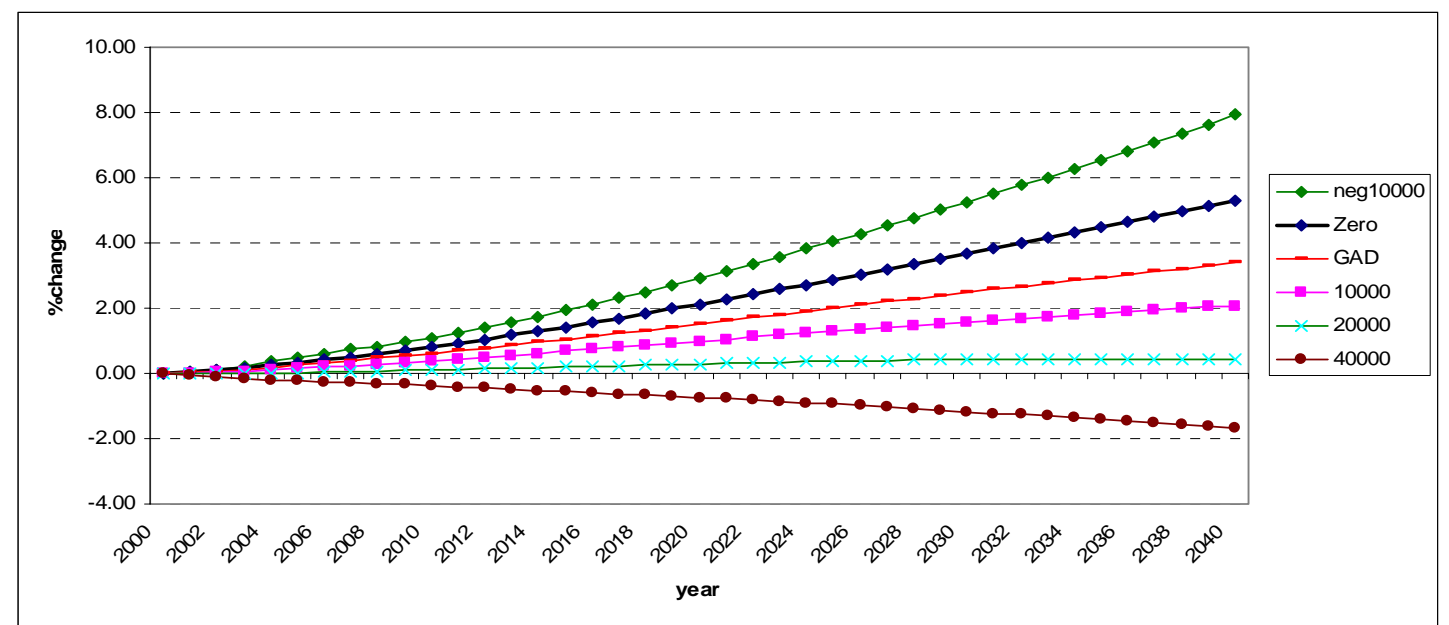

24 


\section{References}

Blanchflower and Oswald, (1994) Blanchflower, D. and Oswald, A. (1994), The Wage Curve, MIT Press, Cambridge, MA.

Economic Policy Committee and the European Commission (2006), The Impact of Ageing on Public Expenditure: Projections for the EU25 Member States on Pensions, Health Care, Long-Term Care, Education and Unemployment Transfers.

Greenaway, D., Leyborne, S.J., Reed G.V. and Whalley, J. (1993), Applied General Equilibrium Modelling: Applications, Limitations and Future Developments, HMSO, London.

Greenwood, M.J., Hunt, G., Richman, D. and Treyz, G. (1991), "Migration, Regional Equilibrium, and the Estimation of Compensating Differentials", American Economic Review, vol. 81, pp. 1382-90.

Harrigan, F., McGregor, P., Perman, R., Swales, K and Yin, Y.P. (1991), “AMOS: A Macro-Micro Model of Scotland”, Economic Modelling, vol. 8, pp. 424-479.

Harris, J. R. and Todaro, M. P. (1970), "Migration, Unemployment, and Development: A Two-Sector Analysis", American Economic Review, vol. 60, pp. 126-142.

Layard, R., Nickell, S. and Jackman, R. (1991), Unemployment: Macroeconomic Performance and the Labour Market, Oxford University Press, Oxford.

McGregor, P. G., Swales, J. K. and Yin, Y. P. (1995), "Input-Output Analysis and Labour Scarcity: Aggregate Demand Disturbances in a "Flex-Price" Leontief System", Economic Systems Research, vol. 7, pp. 189-208.

Minford, P., Stoney, P., Riley, J. and Webb, B. (1994), “An Econometric Model of Merseyside: Validation and Policy Simulations”, Regional Studies, vol. 28, pp. 563575. 
Partridge, M.D. and Rickman D.S., (1998), 'Regional Computable General Equilibrium Modelling: A Survey and Critical Appraisal', International Regional Science Review, vol.21, pp. 205-248.

Treyz, G.I., Rickman, D.S., Hunt G.L. and Greenwood, M.J. (1993), "The Dynamics of Internal Migration in the U.S.", Review of Economics and Statistics, vol. 75, pp. 209-214. 


\section{Appendix 1: The Sectoral Disaggregation in AMOS}

Table A1.1 Sectors (Activities/Commodities) Identified in AMOS

\begin{tabular}{|l|l|l|l|}
\hline & Sector name & IOC codes & SIC \\
\hline 1 & Agriculture & 1 & 1 \\
\hline 2 & Forestry and fishing & $2 \& 3$ & $2,5.01$ \& 5.02 \\
\hline 3 & Mining and quarrying & $4-7$ & $10-14$ \\
\hline 4 & Mfr - food and food processing & $8-20$ & 15 \& 16 \\
\hline 5 & Mfr - textiles and clothing & $21-30$ & $17-19$ \\
\hline 6 & Mfr - chemicals, metals and non-metals & $36-61$ & $24-28$ \\
\hline 7 & Mfr - other manufacturing & $31-35,62-84$ & $20-23,29-37$ \\
\hline 8 & Electricity & 85 & 40.1 \\
\hline 9 & Gas & 86 & $40.2 \& 40.3$ \\
\hline 10 & Water & 87 & 41 \\
\hline 11 & Construction & 88 & 45 \\
\hline 12 & Wholesale and retail distribution & $89-91$ & $50-52$ \\
\hline 13 & Hotels and restaurants & 92 & 55 \\
\hline 14 & Transport & $93-97$ & $60.1-63$ \\
\hline 15 & Communications & $98-99$ & 64 \\
\hline 16 & Banking and other financial services & $100-107$ & $65-72$ \\
\hline 17 & Research and development & 108 & 73 \\
\hline 18 & Legal, accountancy and other business services & $109-114$ & 74 \\
\hline 19 & Public administration & 115 & 75 \\
\hline 20 & Education & 116 & 80 \\
\hline 21 & Health & 117 & $85.1 \& 85.2$ \\
\hline 22 & Social work & 118 & 85.3 \\
\hline 23 & Sewage and refuse disposal & 119 & 90 \\
\hline 24 & Recreational services & 121 & 92 \\
\hline 25 & Other services & $120,122 \& 123$ & $91,93 \& 95$ \\
\hline & & & \\
\hline
\end{tabular}


Appendix 2: The AMOS Model

Table A2.1: A Condensed Version of the AMOS CGE Model

\begin{tabular}{|c|c|}
\hline 1. Commodity Price & $p_{i}=p_{i}\left(w_{n}, w_{k i}\right)$ \\
\hline 2. Consumer Price Index & $c p i=\sum_{i} \theta_{i} p_{i}+\sum_{i} \theta_{i}^{U K} \bar{p}_{i}^{U K}+\sum_{i} \theta_{i}^{R O W} \bar{p}_{i}^{R O W}$ \\
\hline 3. Capital Price Index & $k p i=\sum_{i} \gamma_{i} p_{i}+\sum_{i} \gamma_{i}^{U K} \bar{p}_{i}^{U K}+\sum_{i} \gamma_{i}^{R O W} \bar{p}_{i}^{R O W}$ \\
\hline 4. User Cost of Capital & $u c k=u c k(k p i)$ \\
\hline 5. Wage Equation & $w_{n}=w_{n}(N, \bar{L}, c p i)$ \\
\hline 6. Capital Sock & $K_{i, t}^{S}=\left(1-d_{i}\right) K_{i, t-1}+\Delta K_{i, t-1}$ \\
\hline 7. Labour Demand & $N_{i}^{D}=N_{i}^{D}\left(Q_{i}, w_{n}, w_{k, i}\right)$ \\
\hline 8. Capital Demand & $K_{i}^{D}=K_{i}^{D}\left(Q_{i}, w_{n}, w_{k, i}\right)$ \\
\hline 9. Labour Market Clearing & $\sum_{i} N_{i}^{D}=N$ \\
\hline 10. Capital Market Clearing & $K_{i}^{S}=K_{i}^{D}$ \\
\hline 11. Household Income & $Y=\Psi_{n} N w_{n}+\Psi_{k} \sum_{i} K_{i} w_{k, i}$ \\
\hline 12. Commodity Demand & $Q_{i}=C_{i}+I_{i}+G_{i}+X_{i}$ \\
\hline 13. Consumption Demand & $C_{i}=C_{i}\left(p_{i}, \bar{p}_{i}^{U K}, \bar{p}_{i}^{R O W}, Y, c p i\right)$ \\
\hline 14. Desired Capital Stock & $K_{i}^{*}=K_{i}^{D}\left(Q_{i}, w_{n}, u c k\right)$ \\
\hline 15. Capital Stock Adjustment & $\Delta K_{i}=\lambda_{i}\left(K_{i}^{*}-K_{i}\right)$ \\
\hline 16. Investment Demand & $I_{i}=I_{i}\left(p_{i}, \bar{p}_{i}^{U K}, \bar{p}_{i}^{R O W}, \sum_{i} b_{i, j} \Delta K_{j}\right)$ \\
\hline 17. Government Demand & $G_{i}=\varphi_{i} p_{i} \bar{P}$ \\
\hline 18. Export Demand & $X_{i}=X_{i}\left(p_{i}, \bar{p}_{i}^{U K}, \bar{p}_{i}^{R O W}, \bar{D}^{U K}, \bar{D}^{R O W}\right)$ \\
\hline
\end{tabular}




\section{NOTATION}

\section{Activity-Commodities}

$\mathrm{i}, \mathrm{j}$ are activity/commodity subscripts.

\section{Transactors}

UK = United Kingdom, ROW = Rest of World

\section{Functions}
p (.)
cost function
$\mathrm{w}_{\mathrm{n}}($.$) \quad wage equation$
uck(.) user cost of capital formulation
$\mathrm{K}^{\mathrm{D}}(),. \mathrm{N}^{\mathrm{D}}($.$) \quad factor demand functions$
$\mathrm{C}(),. \mathrm{I}(),. \mathrm{X}($.$) Armington consumption, investment and export demand functions,$ homogenous of degree zero in prices and one in quantities

\section{Variables}

$\begin{array}{ll}\text { C } & \text { consumption } \\ \text { D } & \text { exogenous export demand } \\ \text { G } & \text { government demand for local goods } \\ \text { I } & \text { investment demand for local goods } \\ \Delta K & \text { investment demand by activity } \\ \mathrm{K}^{\mathrm{D}}, \mathrm{K}^{\mathrm{S}}, \mathrm{K}^{*}, \mathrm{~K} & \text { capital demand, capital supply, desired and actual capital stock } \\ \mathrm{L} & \text { labour force } \\ \mathrm{N}^{\mathrm{D}}, \mathrm{N} & \text { labour demand and total employment } \\ \mathrm{P} & \text { population } \\ \mathrm{Q} & \text { commodity/activity output } \\ \mathrm{X} & \text { exports } \\ \mathrm{Y} & \text { household nominal income } \\ \text { b } & \text { elements of capital matrix } \\ \text { cpi, kpi } & \text { consumer and capital price indices } \\ \text { d } & \text { physical depreciation } \\ \mathrm{P} & \text { price of commodity/activity output } \\ \text { t } & \text { time subscript } \\ \text { uck } & \text { user cost of capital }\end{array}$




$\begin{array}{ll}\mathrm{W}_{\mathrm{n}}, \mathrm{w}_{\mathrm{k}} & \text { wage, capital rental } \\ \Psi & \text { share of factor income retained in region } \\ \theta & \text { cpi weights } \\ \gamma & \text { kpi weights } \\ \varphi & \text { government expenditure coefficient } \\ \lambda & \text { capital stock adjustment parameter }\end{array}$

\section{Notes:}

Variables with a bar are exogenous.

A number of simplifications are made in this condensed presentation of AMOS

1. Intermediate demand is suppressed throughout e.g. only primary factor demands are noted in price determination in equation (1) and final demands in the determination of commodity demand in equation (12).

2. Income transfers are generally suppressed.

3. Taxes are ignored.

4. There are implicit time subscripts on all variables. These are only stated explicitly in the capital updating equation (6). 